\title{
Razvojne spremembe v intelektualnem delovanju pri osebah z motnjo v duševnem razvoju
}

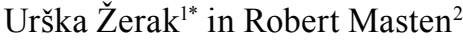 \\ ${ }^{1}$ Oddelek za temeljni pedagoški študij, Pedagoška fakulteta, Univerza v Ljubljani \\ ${ }^{2}$ Oddelek za psihologijo, Filozofska fakulteta, Univerza v Ljubljani
}

\begin{abstract}
Povzetek: Namen pričujoče raziskave je bila retrospektivna vzdolžna analiza sprememb v intelektualnem delovanju pri posameznikih z motnjo v duševnem razvoju (v nadaljevanju MDR), ki so oz. so bili vključeni v Center za usposabljanje, delo in varstvo (v nadaljevanju CUDV) Dolfke Boštjančič Draga. Razvoj posameznikov z MDR se razlikuje od razvoja posameznikov s tipičnim razvojem, saj pri teh posameznikih pogosteje opazimo regresije in nihanja v razvoju. Odvisen je od tipa in obsega osnovne motnje v duševnem razvoju ter komorbidnih zdravstvenih in psihopatoloških stanj. V raziskavo je bilo vključenih 30 posameznikov z zmerno (21) in težjo (9) MDR, ki so bili preizkušani $v$ treh različnih časovnih obdobjih s pripomočkom za merjenje intelektualnih sposobnosti (Valentine test inteligentnosti) z namenom pridobitve vpogleda v razvojne trende spoznavnih sposobnosti proučevane skupine. Skupinska analiza je pokazala statistično značilno izboljšanje dosežkov na merjenem konstruktu med prvim in drugim obdobjem in doslednost med drugim in tretjim preizkušanjem. Dosežki so v času ostali relativno stabilni. Rezultati nakazujejo, da intelektualni razvoj pri posameznikih z MDR poteka po vzporednem modelu razvoja, ki predvideva progresivne spremembe na področju intelektualnega delovanja do 20. leta, nato sledi obdobje doslednosti in upad okoli 60. leta. Predstavljene so tudi omejitve raziskave ter predlogi za nadaljnje raziskovanje.
\end{abstract}

Ključne besede: motnje v duševnem razvoju, inteligentnost, razvoj, vzdolžne študije

\section{Developmental changes in intellectual ability in persons with intellectual disability}

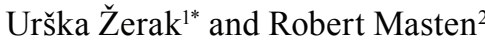 \\ ${ }^{1}$ Department of Education Studies, Faculty of Education, University of Ljubljana, Slovenia \\ ${ }^{2}$ Department of Psychology, Faculty of Arts, University of Ljubljana, Slovenia
}

\begin{abstract}
The aim of the study was a retrospective, longitudinal investigation of changes in intellectual functioning in individuals with intellectual disability who were/are institutionalised. Development of individuals with intellectual disability differs from the development of individuals with typical development, as these individuals frequently demonstrate regressions and fluctuations in development. Their development depends on the type and extent of the intellectual disability, comorbid psychopathology and health conditions. The sample included 30 individuals with moderate (21) and severe (9) intellectual disability who had been assessed in three different time points with an instrument measuring intellectual ability (Valentine intelligence test for children). The group analysis showed a statistically significant improvement in the scores on measured construct between first and second point and continuity of achievements during the second and third point. Results indicate congruity with the similar-trajectory hypothesis, which predicts growth of intellectual abilities up to 20 years, then continuity and decline around age 60 . Limitations and guidelines for future research are also discussed.
\end{abstract}

Key words: intellectual disability, intelligence, development, longitudinal studies

\footnotetext{
*Naslov/Address: Urška Žerak, Oddelek za temeljni pedagoški študij, Pedagoška fakulteta, Univerza v Ljubljani, Kardeljeva ploščad 16, 1000 Ljubljana, e-mail: urska.zerak@pef.uni-lj.si
}

Članek je licenciran pod pogoji Creative Commons Attribution 4.0 International licence. (CC-BY licenca). The article is licensed under a Creative Commons Attribution 4.0 International License (CC-BY license). 
Namen pričujoče raziskave je prispevati $\mathrm{k}$ razširitvi spoznanj o psihološkem delovanju posameznikov z motnjo $\mathrm{v}$ duševnem razvoju(MDR). Proučevana skupina posameznikov je med drugim tudi zaradi heterogenosti ter raznovrstnih pridruženih komorbidnih stanj le redko predmet raziskovanja. Na tem mestu je potrebno izpostaviti specifičnost raziskave, in sicer so bili raziskovalni podatki zbrani retrogradno, kar onemogoča izvedbo nekaterih statističnih analiz in natančnejši vpogled v razvojne trende, kljub temu pa izsledki raziskave prispevajo pomemben dodatni vpogled v razumevanje poteka razvojnih sprememb na področju intelektualnega delovanja oseb z MDR.

\section{Opredelitev motnje v duševnem razvoju}

Opredelitev motnje v duševnem razvoju $\left(\mathrm{MDR}^{1}\right)$ se nekoliko razlikuje glede na mednarodno priznane klasifikacijske sisteme, to so Diagnostični in statistični priročnik duševnih motenj, peta izdaja (Diagnostic and Statistical Manual of Mental Disorders [DSM-V]; American Psychiatric Association [APA], 2013), Mednarodna klasifikacija bolezni, deseta izdaja (MKB-10, v Moravec Berger, 2005) in AAIDD (American Association on Intellectual and Developmental Disorders, 2013), vendar vse opredelitve zajemajo tako primanjkljaje na področju intelektualnega funkcioniranja kot tudi primanjkljaje na področju prilagoditvenih spretnosti. Prav tako postavljajo mejo funkcionalnih primanjkljajev z vrednostjo inteligentnostnega količnika 70 ali manj na zanesljivih, veljavnih in ustrezno standardiziranih psihometričnih instrumentih za ocenjevanje inteligentnosti (Carr in O'Reilly, 2007a).

MDR označuje pomembne omejitve na področju intelektualnega delovanja in na področju prilagoditvenih spretnosti. Intelektualno vedenje se nanaša na sposobnosti

\footnotetext{
${ }^{1}$ Do leta 2007 je v angleščini značilnosti oseb, ki jih v slovenščini opisujemo z izrazom motnja v duševnem razvoju, opisoval izraz mentalna retardacija oz. duševna zaostalost (angl. mental retardation), nato se je namesto njega uveljavil izraz intellectual disability. Zamenjava izraza kaže na spremembe v preusmerjanju poudarka $\mathrm{z}$ opisa motnje $\mathrm{v}$ posamezniku (upočasnjenost oziroma zaostanek njegovega spoznavnega oz. intelektualnega razvoja) na težave, ki so posledica medsebojnega delovanja posameznikovih kapacitet (omejene intelektualne kapacitete so posledica oškodovanosti osrednjega živčevja) pri spoprijemanju z zahtevami okolja, v katerem se nahaja (Kodrič, 2010). V Sloveniji je v uporabi izraz motnja $v$ duševnem razvoju, ki pa ni povsem ustrezen, saj napeljuje na motnjo posameznikovega duševnega delovanja $\mathrm{v}$ celoti, pogosto pa tudi na duševne motnje v smislu psihiatričnih motenj (Stropnik in Kodrič, 2012). Na Oddelku za specialno in rehabilitacijsko pedagogiko Pedagoške fakultete Univerze v Ljubljani strokovnjaki namesto izraza motnja v duševnem razvoju uporabljajo tudi izraz intelektualni primanjkljaj. Na tem mestu z ozirom na opredelitev AAIDD (American Association on Intellectual and Developmental Disabilities, 2013) in na opredelitev pete izdaje Diagnostičnega in statističnega priročnika duševnih motenj (Diagnostic and Statistical Manual of Mental Disorders [DSM-V], 2013) ter glede na argumentacijo, ki jo je v zborniku Psihologija oseb s telesno in povezano duševno zmanjšano zmožnostjo navedel Kovačič (2016), opozarjam na to, da bi bilo $\mathrm{v}$ skladu $\mathrm{z}$ navedenimi argumenti smiselno razmisliti o vpeljavi
}

učenja, mišljenja in reševanja problemov in tudi na sposobnosti, ki zadevajo ostala področja intelektualnega delovanja. Prilagoditvene spretnosti (angl. adaptive behaviour) pa opredeljujejo konceptualne, socialne in praktične veščine (AAIDD, 2013). Nanašajo se na učinkovitost posameznikovega obvladovanja zahtev in standardov za osebno neodvisnost in družbeno odgovornost, kot se jo pričakuje glede na posameznikovo starost, sociokulturno ozadje in širše okolje (APA, 2013). MDR se pojavi pred dopolnjenim 18. letom starosti. Za diagnosticiranje morata biti izpolnjena naslednja dva pogoja, in sicer dosežek na standardiziranem preizkusu inteligentnosti, ki je več kot dva standardna odklona pod povprečjem, ter dosežek na standardiziranem preizkusu prilagoditvenih spretnosti na enem ali več področjih (konceptualnem, socialnem ali praktičnem) več kot dva standardna odklona pod povprečjem (AAIDD, 2013).

Inteligentnost in prilagoditvene spretnosti sta ločena, vendar med seboj povezana konstrukta (Stropnik in Kodrič, 2012). O visoki povezanosti med področjema poročajo avtorji raziskav, v katere so bili vključeni posamezniki z MDR (Kumar, Singh in Akhtar, 2009; Vig in Jedrysek, 1995). Točnega razmerja med vedenjsko prilagojenostjo in inteligentnostjo skozi razvoj ni možno določiti zaradi pomanjkanja jasnih, neprekrivajočih se definicij za vsakega izmed konstruktov in zaradi različnosti instrumentov, ki se $\mathrm{v}$ raziskavah uporabljajo za merjenje teh dveh konstruktov (Loveland in Tunali-Kotolski, 1998).

MDR se razprostira na kontinuumu od lažje do težke. Posamezniki z lažjo MDR imajo razpon inteligentnostnega količnika (v nadaljevanju IQ) pod 70 in nad 50-55. Mentalna starost odraslih je od devet do 12 let. Prav tako imajo primerljivo raven primanjkljajev na področju prilagoditvenih spretnosti. Posamezniki z zmerno MDR imajo razpon IQ nad 35-40 in pod 50-55. Mentalna starost odraslih je od šest do devet let. Kaže se tudi primerljiva raven primanjkljajev na področju prilagoditvenih spretnosti. Posamezniki s težjo MDR imajo razpon IQ nad 20-25 in pod 35-40. Mentalna starost odraslih je od tri do šest let. Imajo tudi primerljivo raven primanjkljajev na področju prilagoditvenih spretnosti. Posamezniki s težko MDR imajo razpon IQ pod 20-25. Mentalna starosti odraslih je do tri leta. Izkazujejo zelo izrazit razvojni zaostanek pri pridobivanju veščin grobe motorike, fine senzomotorike, komunikacijskih ter prilagoditvenih veščin (Carr in O’Reilly, 2007a).

\section{Intelektualni razvoj oseb z motnjo v duševnem razvoju}

Razvoj posameznika z MDR je odvisen od tipa in obsega osnovne motnje $\mathrm{v}$ duševnem razvoju, komorbidnih zdravstvenih stanj (npr. slepota, gibalna oviranost, epilepsija), dejavnikov okolja, psiholoških dejavnikov, kognitivnih sposobnosti in komorbidnih psihopatoloških stanj (Kumar idr. 2009).

Spoznavni razvoj glede na Piagetove faze razvoja, ki potekajo progresivno iz enega stadija $\mathrm{v}$ drugega, poteka pri osebah z MDR podobno, le nekoliko počasneje $\mathrm{v}$ primerjavi z osebami z normativnim razvojem (Carr in O'Reilly, 2007b). Goodman in Cameron (1978) sta na podlagi svoje raziskave, v 
kateri sta zbrala podatke psiholoških ocenjevanj spoznavnih sposobnosti klinične populacije 289 otrok s sumom na razvojni zaostanek, ki so bili spremljani od rojstva do devetega leta starosti v časovnih razmikih po dve leti, prišla do ugotovitve, da je IQ otrok z razvojnim zaostankom bolj stabilen kot IQ otrok z normativnim razvojem. Na podlagi tega bi lahko sklepali, da razvoj pri teh otrocih napreduje v intelektualnem smislu na ravni, ki je proporcionalna ravni normativnih otrok glede na njihovo mentalno in ne kronološko starost. Avtorja predpostavljata, da spoznavni razvoj pri posameznikih z MDR poteka počasneje ter da ti posamezniki tudi kasneje dosežejo plato v razvoju intelektualnih sposobnosti.

Fisher in Zeaman (1970) sta predlagala tri možne modele razvoja inteligentnosti pri osebah z MDR, ki so osnovani na podlagi primerjave razvoja inteligentnosti $\mathrm{z}$ normativno populacijo: okrnjen, vzporeden in kompenzacijski. Ti modeli so osnovani na tradicionalnih teorijah inteligentnosti $\mathrm{v}$ splošni populaciji, po katerih splošna inteligentnost - brez razlikovanja med kristalizirano in fluidno - narašča linearno do 20. leta, nato pa sledi stabilnost in upad okrog 60. leta. Do leta 1980 je bila v veljavi predpostavka o pospešenem kognitivnem upadu pri posameznikih z MDR (Fisher in Zeaman, 1970). Temeljila je na modelu okrnjenosti, ki predvideva, da osebe z MDR kažejo omejitve v intelektualnem razvoju pred 20. letom. Vrh intelektualnih sposobnosti dosežejo v starosti 10.-15. let, nato pa sposobnosti ostanejo stabilne in zgodaj upadejo (okrog 30.-40. leta). V 90. letih se je nato na podlagi razvojnopsihološkega modela avtorjev Hodapp, Burack in Zigler (1998) uveljavila predpostavka o vzporednem razvoju, ki predvideva, da intelektualni razvoj pri posameznikih z MDR poteka podobno kot pri normativni populaciji. Vrh doseže okoli 20. leta, nato je stabilen in upade okoli 60. leta. Glede na ta model posamezniki z MDR izkazujejo počasnejši vzorec rasti kognitivnih sposobnosti $\mathrm{v}$ primerjavi s posamezniki s tipičnim razvojem, vendar pa izkazujejo podoben, vzporeden vzorec stabilnosti in upada kognitivnih sposobnosti. Model so podprle ugotovitve Facona (2008), ki je v svoji raziskavi ugotovil, da odrasli z ali brez motnje v duševnem razvoju (stari med 20 in 54 let) kažejo z naraščajočo starostjo podoben razvoj kristalizirane in fluidne inteligentnosti. V. Bužan (1994) je v slovenski raziskavi, v katero so bili vključeni otroci z MDR, ugotovila, da njihov intelektualni razvoj poteka glede na Piagetove faze spoznavnega razvoja po enakih razvojnih stopnjah kot pri otrocih brez motenj, vendar upočasnjeno. Največji porast se je pokazal v obdobju od sedmega do osmega leta starosti. Razvoj se ni zaključil pri 14.-15. letih, temveč je bil napredek $\mathrm{v}$ razvoju opazen tudi po 21 . letu starosti.

V zadnjih letih pa je Lifshitz-Vahav (2014) predlagal kompenzacijski model intelektualnega razvoja. Predpostavka tega modela je, da je obdobje progresivnih sprememb $\mathrm{v}$ intelektualnem razvoju daljše pri osebah $\mathrm{z}$ MDR in da intelektualni razvoj poteka do 50. leta, nato sledi obdobje relativne stabilnosti od 50. do 60. leta, nakar se pojavi upad. Kompenzacijski model so podprle ugotovitve raziskovalcev (Lifshitz, Weiss, Tzuriel in Tzemach, 2010), ki so proučevali vpliv poučevanja na reševanje analognih problemov pri mladostnikih (starih od 13 do 21 let) in odraslih (starih od
25 do 66 let) z MDR. Njihov IQ se je gibal med 40 in 70 . Ugotovili so, da so po poučevanju odrasli z MDR dosegli boljše rezultate $\mathrm{v}$ primerjavi $\mathrm{z}$ mladostniki $\mathrm{z}$ MDR, kar lahko nakazuje na to, da se razvoj kognitivnih sposobnosti nadaljuje v obdobje srednje in pozne odraslosti. Do podobnih zaključkov sta na podlagi svoje študije prišla tudi Fisher in Zeaman (1970), in sicer sta ugotovila, da posamezniki z MDR ne dosežejo najvišje ravni mentalne starosti do 35. leta, temveč se razvoj nadaljuje tudi po 35 . letu. Udeleženci v vzorcu so namreč napredovali v dosežkih tudi po 35. letu, kar nakazuje na to, da je intelektualni razvoj zapoznel.

Izsledki raziskav o intelektualnem razvoju posameznikov zMDRniso enoznačni. Raziskave posameznikovs specifičnim organskim vzrokom MDR (npr. Downov sindrom) nakazujejo, da se pri teh posameznikih pridobivanje akademskih (šolski uspeh), motoričnih in jezikovnih veščin nadaljuje vsaj do obdobja zgodnje odraslosti (Udwin in Kuczynski, 2007). J. Carr (1988, 2005) je v obsežni longitudinalni raziskavi posameznikov z Downovim sindromom ugotovila, da je zanje značilen upad v standardiziranih vrednostih IQ od šestih mesecev do 11 let, nato pa so povprečne vrednosti IQ do 21. leta naraščale, in sicer v povprečju za 4,7 točk v obdobju desetih let. V odraslosti (Carr, 2012) pa se je na istem vzorcu posameznikov od 21. leta do 45. leta pokazal upad, ki je bil značilen za ženske, nasprotno pa moški niso izkazovali značilnejšega upada. Pri tem je treba upoštevati, da lahko upad pri posameznicah v vzorcu pripišemo vplivu demence. $Z$ izjemo posameznic $\mathrm{z}$ demenco so udeleženci $\mathrm{v}$ vzorcu v obdobju od 21. do 45. leta v povprečju izgubili manj kot eno IQ točko pri neverbalnem IQ in pridobili pet točk pri verbalnem IQ v obdobju 24 let (Carr, 2012).

Določene longitudinalne raziskave (Dykens, Hodapp, Walsh in Nash, 1992; Hall, Burns in Lightbody, 2008) kažejo podobno kot longitudinalna študija avtorice J. Carr (1988, 2005, 2012) na relativno stabilnost $v$ dosežkih na področju intelektualnega funkcioniranja pri osebah z MDR. Nasprotno pa ugotovitve longitudinalne študije, $\mathrm{v}$ kateri so avtorji spremljali razvoj otrok z MDR od tretjega do enajstega leta starosti, kažejo na upad dosežkov pri posameznikih v vzorcu na področju intelektualnega delovanja (Keogh, Bernheimer in Guthrie, 1997).

\section{Raziskovalni problem}

Namen raziskave je bil vzdolžno proučiti spremembe $\mathrm{v}$ intelektualnem delovanju oseb z motnjo v duševnem razvoju. Ugotovitve raziskovalcev o intelektualnem razvoju oseb z MDR niso enoznačne in podpirajo tri možne modele razvoja: okrnjen, vzporeden (Facon, 2008) in kompenzacijski (Lifshitz idr., 2010). Pregled slovenske literature nam pokaže, da je v Sloveniji obravnavana populacija le redko proučevana $\mathrm{v}$ smislu psihološkega delovanja. S področjem intelektualnega razvoja oseb z MDR se je ukvarjala le ena raziskovalka, in sicer V. Bužan (1994). Za nudenje optimalne podpore in ustrezno obravnavo oseb z MDR je bistveno natančno poznavanje poteka njihovega razvoja in cilj pričujoče študije je prispevati k razširitvi spoznanj o poteku razvojnih trendov proučevane populacije. 
$\mathrm{V}$ raziskavi je bila uporabljena retrospektivna longitudinalna analiza podatkov o intelektualnem delovanju oseb z zmerno in težjo MDR z namenom pridobitve vpogleda $v$ potek razvojnih trendov proučevane populacije. Analizirani podatki so bili zbrani na podlagi psiholoških testiranj varovancev v obdobju 30-letnega delovanja CUDV Dolfke Boštjančič Draga. Zaradi priložnosti dostopa do psihodiagnostičnih podatkov in zaradi analize pridobljenih podatkov v obdobju 30-letnega delovanja centra je bil $\mathrm{v}$ raziskavi uporabljen specifičen psihodiagnostičen pripomoček, ki je bil v uporabi od začetka delovanja centra.

\section{Metoda}

\section{Udeleženci}

$\mathrm{V}$ raziskavi je sodelovalo 30 udeležencev z zmerno $(N=$ $21)$ in težjo $(N=9)$ MDR, ki so oz. so bili vključeni v CUDV Dolfke Boštjančič Draga. Od tega je bilo 14 moških in 16 žensk. Pri prvem merjenju se je starost udeležencev gibala od 6 do 15 let $(M=11, S D=3,44)$, pri drugem od 12 do 28 let $(M=19, S D=5,15)$ in pri tretjem od 18 do 40 let $(M=$ $26, S D=6,24)$. Starostno so bili udeleženci z zmerno in težjo MDR pri posameznih merjenjih približno enako razporejeni. $\mathrm{V}$ raziskavo je bilo glede na komorbidnost vključenih pet posameznikov z Downovim sindromom, štirje z epilepsijo ter dvazlažjo govornojezikovno motnjo, lažjo gibalno oviranostjo in dolgotrajno boleznijo. V vzorcu so bile pri posameznikih zastopane tudi naslednje komorbidnosti: centralna motorična prizadetost, cerebralna disfunkcija, Landau-Kleffnerjev sindrom, organska cerebralna oškodovanost, eretičnost, patološko nerazvit govor, razvojni zaostanek na področju govora in jezika, reaktivne čustvene motnje, slepota, težave na področju socialne in emocionalne odzivnosti. Ostalih 11 posameznikov v vzorcu ni imelo pridruženih komorbidnih stanj oz. ta stanja niso bila navedena $\mathrm{v}$ psiholoških poročilih. Treba je poudariti, da je bil proučevan vzorec glede na proučevane parametre znotraj skupin posameznikov z zmerno in težjo MDR izjemno heterogen (različna komorbidna stanja). Zaradi majhnega vzorca in večje heterogenosti znotraj posameznih skupin v primerjavi s heterogenostjo med skupinami smo se odločili za skupinsko analizo podatkov ter analizo individualnih dosežkov pri posameznikih v vzorcu.

\section{Pripomočki}

Valentine test inteligentnosti. Test (Intelligence Test for Children, Valentine, 1953; slovensko priredbo je opravil Toličič, 1962) obsega 128 nalog, ki so razdeljene po težavnosti v 17 starostnih skupin. Vsaka izmed njih vsebuje od 6 do 10 nalog, ki ustrezajo določeni mentalni starosti otroka. Prva težavnostna skupina vsebuje naloge, ki ustrezajo mentalni starosti enega leta in pol, zadnja težavnostna skupina pa vsebuje naloge, ki ustrezajo mentalni starosti 15 let. Težavnostne skupine si do četrtega leta mentalne starosti sledijo v intervalu šestih mesecev, od četrtega do 15. leta pa $\mathrm{v}$ razmiku enega leta. Različne težavnostne stopnje vsebujejo različne naloge, ker se inteligentnost skozi različna razvojna obdobja kaže na različne načine. Pri nižjih starostih (npr. 1,5 let mentalne starosti) prevladujejo naloge $s$ področja senzomotorike in posnemanja. Pri srednjih starostih (npr. 4-8 let mentalne starosti) prevladujejo naloge preštevanja, sklepanja, ponavljanja števil ter reševanja labirintov in analogij. Pri najvišjih starostih (14 in 15 let mentalne starosti) pa prevladujejo naloge sklepanja, uvidevanja protislovij, reševanja labirintov in risanja (Svetina, 2002). Pričnemo z nalogami za najnižjo starostno skupino. Testiranje poteka dokler posameznik za določeno starostno obdobje ne reši več nobene naloge. Ocenjene so $\mathrm{z}$ določenim številom točk (ena točka, pol točke oz. četrtina točke), in sicer sorazmerno z zahtevnostjo. Način točkovanja je podan pri posamezni testni nalogi. Na podlagi uspešnosti posameznika pri reševanju nalog za določeno mentalno starost in točkovanja se dosežek posameznika na testu pretvori $\mathrm{v}$ oceno mentalne starosti (Bužan, 1994). V raziskavi smo dosežke posameznikov na Valentine testu pretvorili v oceno njihove mentalne starosti pri posameznem testiranju. Svetina (1996, citirano v: Svetina, 2002) je v pilotni študiji ocenjeval težavnost nalog v Valentine testu inteligentnosti za otroke. Nekatere naloge so bile zaradi neustreznosti izpuščene, v nekaterih pa je bilo spremenjeno navodilo ali slikovni material. Koeficient notranje zanesljivosti nekoliko prirejenega Valentine testa je znašal 0,89 (Svetina, 2002). V pričujoči študiji je koeficient notranje zanesljivosti testa znašal 0,87. Omeniti velja, da se test uporablja oz. se je uporabljal zato, ker v Sloveniji nimamo standardiziranega testa za diagnosticiranje intelektualnega delovanja oseb z MDR. V. Bužan (1994) navaja, da je v primerjavi z WISC-om uporabnejši, saj je uporaben tudi pri otrocih, ki imajo nižje intelektualne sposobnosti, njihova kronološka starost pa je višja.

\section{Postopek}

Od psihologov, zaposlenih v CUDV Dolfke Boštjančič Draga, smo pridobili osebne podatke udeležencev (rojstni datum, datume preizkušanja $\mathrm{z}$ navedenim pripomočkom, spol, starost, stopnjo MDR, komorbidnost) ter rezultate treh preizkušanj v različnih razvojnih obdobjih (srednje in pozno otroštvo, mladostništvo, zgodnja odraslost) na Valentine testu inteligentnosti. V raziskavo smo na podlagi pregleda psihološke dokumentacije varovancev CUDV Dolfke Boštjančič Draga vključili posameznike, ki so bili $\mathrm{z}$ navedenim pripomočkom testirani v zgoraj navedenih razvojnih obdobjih. Namen testiranj je bilo spremljanje njihovega razvoja na področju intelektualnega delovanja.

Pridobljeni podatki so bili obdelani s pomočjo statističnega programa SPSS. Za analizo podatkov smo uporabili enosmerno ANOVO za ponovljene meritve. Za ugotavljanje razlik med posameznimi merjenji smo uporabili $t$-test za odvisne vzorce, pri čemer smo zaradi multiplih primerjav upoštevali Bonferronijev popravek.

Časovna razlika med prvim in drugim merjenjem se je gibala od 4 do 13 let $(M=8,0 ; S D=3,6)$, med drugim in tretjim merjenjem pa se je časovna razlika gibala od 5 do 17 let $(M=8,0 ; S D=3,3)$. 


\section{Rezultati}

V prvem delu so predstavljene mere opisne statistike ter skupinska analiza dosežkov na Valentine testu inteligentnosti, pri tem pa smo dosežke posameznikov na testu pretvorili $\mathrm{v}$ oceno mentalne starosti. Podatke smo analizirali s pomočjo enosmerne analize variance (ANOVE) za ponovljene meritve ter $t$-testov za odvisne vzorce. Za namen preverjanja relativne stabilnosti dosežkov posameznikov v času smo izračunali tudi Pearsonove koeficiente korelacije med posameznimi merjenji. V drugem delu smo s pomočjo prikaza individualnih dosežkov posameznikov z zmerno in težjo MDR analizirali spremembe v dosežkih posameznikov ob vsakem merjenju.

\section{Skupinska analiza dosežkov}

Tabela 1 prikazuje mere opisne statistike na Valentine testu inteligentnosti glede na izračunano mentalno starost $\mathrm{v}$ letih pri udeležencih. Iz tabele 1 lahko razberemo, da so srednje vrednosti mentalne starosti udeležencev ( $\mathrm{v}$ nadaljevanju točke) na Valentine testu inteligentnosti od prvega do drugega merjenja narasle s 3,64 na 4,81 točk ter od drugega do tretjega merjenja na 5,02 točke. Razpon dosežkov na Valentine testu inteligentnosti se giblje od 1,5 do 15 točk. Potrebno pa je omeniti, da so bili posamezniki v vzorcu različnih starosti ob posameznih merjenjih, a nam ti rezultati vseeno nakazujejo, da s časom prihaja do porasta intelektualnih sposobnosti pri posameznikih v vzorcu. Individualen pregled dosežkov posameznikov pokaže precejšnje medosebne razlike $\mathrm{v}$ dosežkih, za katere domnevamo, da so vsaj delno odraz zgoraj omenjene starostne heterogenosti udeležencev.

Za preverjanje glavnega učinka časa na spremembe $\mathrm{v}$ dosežkih na Valentine testu inteligentnosti smo izvedli enosmerno analizo variance (ANOVA) za ponovljene meritve. Sprva smo preverili ustreznost podatkov glede na predpostavke ANOVE za ponovljene meritve: da v podatkih ni osamelcev, da so vrednosti odvisne spremenljivke normalno porazdeljene $\mathrm{v}$ vseh skupinah udeležencev ter predpostavko sferičnosti, ki pravi, da morajo vse parne razlike med ravnmi neodvisne spremenljivke imeti enake variance. Mauchlijev test je pokazal, da je bila predpostavka sferičnosti kršena, $\chi^{2}(2)=6,21, p<0,05$, zato so bile stopnje svobode pri analizi korigirane s Huynh-Feldtovim popravkom $(\varepsilon=0,88)$.

Analiza variance je pokazala statistično značilen velik učinek vpliva časa na spremembe v dosežkih, $F(1,76 ; 50,98)$ $=36,72, p<0,001 ; \eta_{\mathrm{p}}{ }^{2}=0,56$. Da bi preverili razlike med posameznimi merjenji, smo izvedli tri $t$-teste za odvisne vzorce z Bonferronijevim popravkom za multiple primerjave.

Tabela 1. Mere opisne statistike na Valentine testu inteligentnosti $(N=30)$

\begin{tabular}{lcccc}
\hline & $\min$ & $\max$ & $M$ & $S D$ \\
\hline 1. merjenje & 1,10 & 7,30 & 3,64 & 1,23 \\
2. merjenje & 2,00 & 7,87 & 4,81 & 1,34 \\
3. merjenje & 1,70 & 8,00 & 5,02 & 1,29 \\
\hline
\end{tabular}

Opomba. Vrednosti predstavljajo dosežke posameznikov, ki so pretvorjeni v oceno mentalne starosti.
Rezultati so pokazali, da je med prvim $(M=3,64, S D=$ $1,23)$ in drugim $(M=4,81, S D=1,34)$ merjenjem prišlo do statistično značilnih in velikih sprememb v dosežkih, $t(29)$ $=7,69, p<0,001 ; d=0,91$. Nasprotno učinek časa med drugim in tretjim merjenjem ni bil statistično značilen, $t(29)=1,39, p=0,18, d=0,16$. Spremembe v dosežkih med $\operatorname{prvim}(M=3,64, S D=1,23)$ in tretjim $(M=5,02, S D=1,29)$ merjenjem so bile statistično značilne, $t(29)=6,62, p<0,001$, $d=1,10$.

Poleg tega smo z izračuni korelacij med dosežki posameznikov ob posameznih merjenjih ocenjevali relativno stabilnost intelektualnega delovanja $\mathrm{v}$ času. Med dosežki na 1 . in 2. merjenju in med dosežki na 2. in 3. merjenju je Pearsonov $r$ znašal 0,79 , med dosežki na 2. in 3. merjenju pa 0,59 (vse korelacije so bile statistično značilne na 1-odstotni ravni tveganja). Na podlagi teh korelacij lahko zaključimo, da so dosežki udeležencev na Valentine testu inteligentnosti relativno stabilni. Natančneje, med posameznima sočasnima merjenjema (med prvim in drugim ter drugim in tretjim) je bila relativna stabilnost visoka, tudi v daljšem časovnem razmaku (med prvim in tretjim merjenjem) pa je ostala zmerna.

\section{Analiza individualnih dosežkov}

Ker so bili udeleženci že v času merjenja precej različnih starosti, poleg tega pa so se tudi časovni razmiki med posameznimi merjenji precej razlikovali med udeleženci, prikazujemo tudi dosežke posameznikov ob vsakem merjenju, in sicer posebej za osebe z zmerno MDR (slika 1) in osebe s težjo MDR (slika 2). Slika 1 prikazuje splošen trend v smeri naraščanja individualnih dosežkov udeležencev z zmerno MDR do obdobja zgodnje odraslosti. Dosežki med prvim in drugim merjenjem so se povečali pri 20 udeležencih ter se zmanjšali pri eni osebi. Med drugim in tretjim časovnim obdobjem so dosežki pri petih osebah ostali na isti ravni, pri štirih so se zmanjšali, pri 12 osebah pa povečali.

Slika 2 prikazuje splošen trend $\mathrm{v}$ smeri naraščanja individualnih dosežkov udeležencev s težjo MDR do obdobja

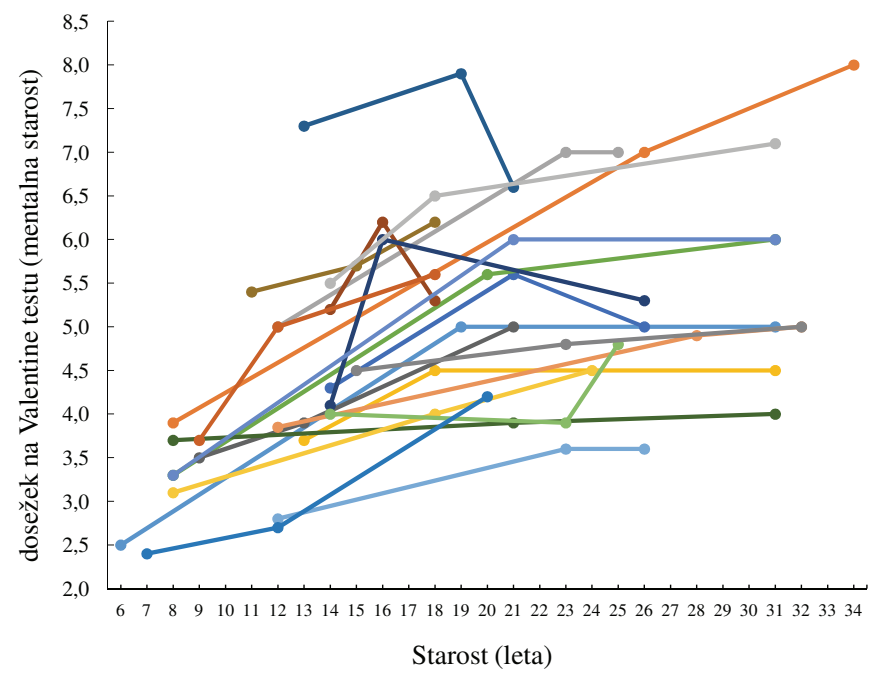

Slika 1. Prikaz individualnih dosežkov udeležencev z zmerno MDR na Valentine testu. 


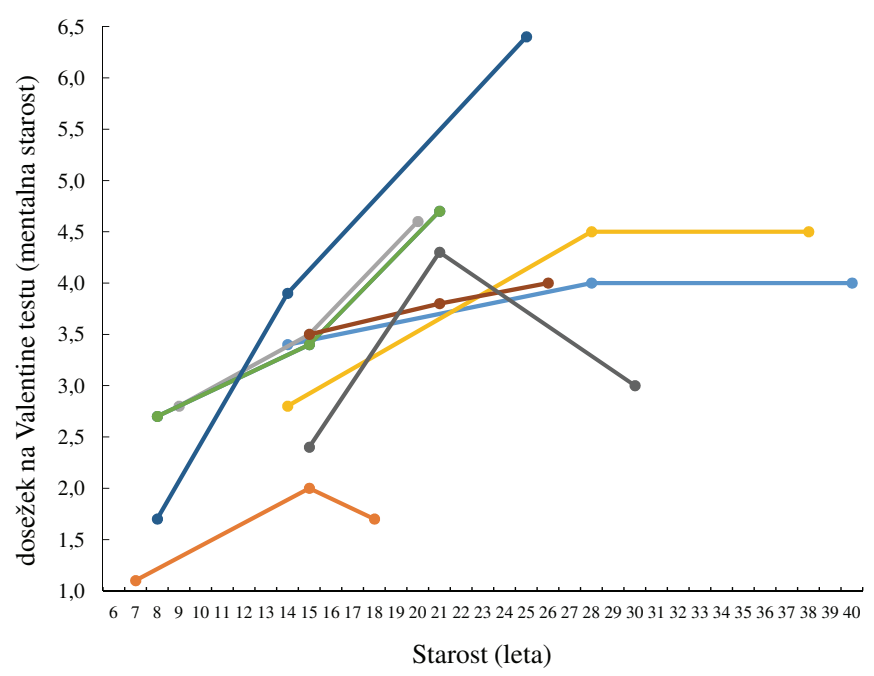

Slika 2. Prikaz individualnih dosežkov udeležencev s težjo MDR na Valentine testu.

zgodnje odraslosti. Dosežki med prvim in drugim časovnim obdobjem so se povečali pri vseh devetih udeležencih s težjo MDR. Med drugim in tretjim časovnim obdobjem so dosežki pri dveh osebah ostali na isti ravni, pri treh so se zmanjšali, pri štirih osebah pa povečali.

Na podlagi primerjave individualnih dosežkov posameznikov na Valentine testu (slika 1 in slika 2) lahko opazimo, da se pri obeh skupinah udeležencev (zmerna in težja MDR) nakazuje podoben trend razvojnih sprememb na področju intelektualnega delovanja.

\section{Razprava}

$\mathrm{V}$ raziskavi smo proučevali razvojne trende na področju intelektualnega delovanja posameznikov z zmerno in težjo MDR v obdobju od srednjega in poznega otroštva do zgodnje odraslosti.

Analiza poteka intelektualnega delovanja na ravni posameznikov nam je omogočila bolj natančno proučevanje poteka spoznavnega razvoja, saj je bila skupina udeležencev starostno precej heterogena, precejšnje razlike pa so bile tudi $\mathrm{v}$ časovnih razmakih med merjenji. Nadalje so bili $\mathrm{v}$ vzorec vključeni posamezniki z različnimi komorbidnimi stanji (Downov sindrom, epilepsija ipd.), ki vplivajo na posameznikov spoznavni razvoj. S pomočjo analize na ravni posameznika so bolj vidne medosebne razlike $\mathrm{v}$ poteku razvoja intelektualnega delovanja, ki se v analizi povprečnih dosežkov porazgubijo. Pregled individualnih dosežkov nakazuje na splošen trend v smeri naraščanja dosežkov na področju intelektualnega delovanja pri večini udeležencev (96,7 \%) v vzorcu od šestega do 25. leta, temu pa sledi obdobje stabilnosti oz. zelo rahlo naraščanje dosežkov, ki je značilno za polovico posameznikov (53,3 \%) v vzorcu. Pri tem se pri obeh skupinah udeležencev (zmerna in težja MDR) nakazuje podoben trend v smeri naraščanja dosežkov udeležencev. Na tem mestu je potrebno izpostaviti, da udeleženci v našem vzorcu niso bili spremljani do obdobja srednje oz. pozne odraslosti, tako da na podlagi dobljenih rezultatov ne moremo predvidevati nadaljnjega poteka razvoja intelektualnih sposobnosti, vendar pa rezultati nakazujejo, da vsaj pri večini posameznikov ne pride do upada že okrog 30. leta, kot predvideva okrnjen model razvoja inteligentnosti pri osebah z MDR (Fisher in Zeaman, 1970).

Podobno so pokazali tudi rezultati analize variance za ponovljene meritve in sicer, da je bil glavni učinek časa na spremembe $\mathrm{v}$ dosežkih velik in statistično značilen med 1 . in 2. merjenjem, med 2. in 3. merjenjem pa se kaže doslednost dosežkov udeležencev. Dobljeni rezultati nakazujejo v smer skladnosti s hipotezo o vzporednem intelektualnem razvoju, ki pravi, da se intelektualne sposobnosti pri posameznikih z MDR razvijajo do okrog 20. leta, nato so stabilne in upadejo okrog 60. leta (Facon, 2008). Pri tem je potrebno opozoriti, da pri nobenem izmed udeležencev nismo ocenjevali intelektualnih sposobnosti po 40. letu starosti. Upoštevajoč navedeno na podlagi pridobljenih rezultatov nismo mogli preveriti predpostavke kompenzacijskega modela (LifshitzVahav, 2014), ki pravi, da intelektualni razvoj oseb z MDR poteka do 50. leta, nato sledi obdobje relativne stabilnosti od 50. do 60 leta, potem pa se pojavi upad.

$\mathrm{V}$ longitudinalni študiji posameznikov $\mathrm{z}$ MDR in Downovim sindomom, ki jo je izvedla J. Carr (1998, 2005, 2012) so udeleženci v obdobju od šestega meseca do 11. leta starosti imeli nižje IQ točke, nato pa so se v obdobju nadaljnjega desetletnega spremljanja udeležencev nekoliko povečale (v povprečju za 4,7 točk). Podoben trend nakazujejo tudi rezultati naše raziskave, saj so se dosežki na področju intelektualnih sposobnosti udeležencev v vzorcu statistično značilno povečali od prvega merjenja $\left(M_{\text {starost }}=11\right.$ let $)$ do drugega merjenja $\left(M_{\text {starost }}=19\right.$ let $)$.

$\mathrm{Na}$ drugi strani pa so dobljeni rezultati $\mathrm{v}$ nasprotju $\mathrm{Z}$ ugotovitvami longitudinalne študije spoznavnega razvoja otrok z MDR (Koegh idr., 1997), v kateri so raziskovalci poročali o upadu dosežkov na področju intelektualnega funkcioniranja. Predpostavljamo, da napredek pri udeležencih v proučevanem vzorcu lahko delno pripišemo dejstvu, da so bili udeleženci nameščeni $\mathrm{v}$ ustreznem podpornem okolju (CUDV), kjer so bili deležni individualizirane obravnave na dnevni ravni. Ustrezno podporno okolje jim namreč omogoča razvoj in pridobivanje novih veščin, ki se lahko odražajo tudi $\mathrm{v}$ boljšem intelektualnem funkcioniranju.

Naraščanje dosežkov na področju intelektualnega funkcioniranja oz. mentalne starosti udeležencev bi lahko pripisali tudi vplivu izkušenj oz. razvoju kristalizirane inteligentnosti. Po ugotovitvah Faconove študije (2008) odrasli z MDR izkazujejo z naraščajočo starostjo podoben razvoj tako fluidne kot tudi kristalizirane inteligentnosti v primerjavi z normativno populacijo. J. Carr (2012) je kot možno razlago za porast na področju intelektualnih sposobnosti pri udeležencih (od 11. leta do 21. leta za neverbalne oz. do 30. leta za verbalne sposobnosti) navedla različne zahteve merskih instrumentov na različnih ravneh kompleksnosti. Ta navedba je skladna z ugotovitvami Kaufmana s sodelavci (Kaufman, Reynolds in McLean, 1989), ki je v prečni študiji ugotovil, da so dosežki v splošni populaciji pri tistih, ki so se izobraževali od 0 do 8 let, upadli od 20. do 74 . leta za 9,3 točke $\mathrm{v}$ primerjavi $\mathrm{z}$ upadom 20,7 točk pri tistih, ki so se izobraževali vsaj 16 let. J. Carr (2012) je zaključila, da bi to 
lahko morda pripisali temu, da so bolj kompleksni neverbalni procesi manj vtisnjeni v posameznikov repertoar veščin in jih zato lažje izgubi v primerjavi z bolj splošnimi oz. bazičnimi.

Dobljene visoke in zmerno visoke povezanosti med dosežki na področju intelektualnega delovanja med posameznimi merjenji nakazujejo, da so dosežki relativno stabilni, kar pomeni, da so udeleženci ohranili svoj relativni položaj v skupini. Na relativno stabilnost dosežkov na področju intelektualnega delovanja pri osebah z MDR nakazujejo tudi nekatere longitudinalne raziskave (Carr, 1988, 2005, 2012; Dykens idr., 1992; Hall idr., 2008). Ne glede na nižjo raven intelektualnega delovanja pri osebah z MDR v primerjavi z normativno populacijo je tudi pri osebah z MDR intelektualno delovanje precej stabilno. Iz tega vidika je slovenska zakonodaja na tem področju ustrezna, saj določa, da imajo osebe z MDR pravico do vključenosti v program izobraževanja do vključno 26. leta starosti (Zakon o usmerjanju otrok s posebnimi potrebami, 2011).

\section{Omejitve raziskave in smernice za prihodnje raziskave}

Kot pomanjkljivost raziskave je treba na začetku izpostaviti majhen vzorec ter heterogenost udeležencev glede na prisotna komorbidna stanja in starost. Raziskava je bila izvedena na udeležencih, ki so v času vseh treh preizkušanj bivali v CUDV Dolfke Boštjančič Draga, kar pa omejuje posplošitev rezultatov. Na rezultate raziskave so vplivale tudi značilnosti psihološkega merskega instrumenta, ki ni prilagojen oz. je manj prilagojen za osebe z MDR. Psihodiagnostični podatki so bili pridobljeni retrogradno in intervali med preizkušanji niso bili enaki pri vseh udeležencih. Nadalje je treba upoštevati omejitve v veljavnosti ocenjevalnega pripomočka, težave pri motiviranju in vzdrževanju pozornosti med samim postopkom testiranja (gre namreč za specifično populacijo) ter ostale dejavnike (okolje, družina), ki vplivajo na dosežek $\mathrm{v}$ času ocenjevanja. V raziskavi ni bil proučevan in upoštevan vpliv sprememb v psihosocialnem okolju, prav tako nismo proučili vpliva osebnostnih in motivacijskih dejavnikov. Nadaljnje raziskave z vključitvijo omenjenih dejavnikov bi bile zanimive, relevantne in smiselne.

$\mathrm{V}$ prihodnje bi bilo poleg upoštevanja vpliva navedenih dejavnikov priporočljivo primerjati posameznike z MDR s posamezniki iste mentalne starosti oz. kronološke starosti z normativnim razvojem. Prav tako bi bilo smiselno udeležence spremljati skozi daljše časovno obdobje, in sicer do srednje in pozne odraslosti. Tako bi dobili še boljši in natančnejši vpogled v razvojne trende. Zanimive bi bile tudi analize razvojnih trendov pri specifičnih sindromih, npr. pri Downovem sindromu in ostalih organskih vzrokih za motnjo v duševnem razvoju. Raziskave iz tujine namreč kažejo, da gre pri specifičnih sindromih za specifične razvojne trende in vzorce funkcioniranja, ki se med seboj nekoliko razlikujejo.

\section{Literatura}

AAIDD (2013). Definition of Intellectual Disability, Frequently Asked Questions on Intellectual Disability and the AAIDD definition. Pridobljeno s strani http:// www.aaidd.org

APA (2013). Diagnostic and statistical manual of mental disorders (5th ed.). Washington, DC, ZDA: Author.

Bužan, V. (1994). Intelektualni razvoj otrok z zmerno in težjo MDR [Intellectual development of children with moderate and severe intellectual disability] (neobjavljeno magistrsko delo). Filozofska fakulteta Univerze v Ljubljani, Slovenija.

Carr, A. in O'Reilly, G. (2007a). Diagnosis, classification and epidemiology. V A. Carr, G. O'Reilly, P. N. Walsh in J. McEvoy (ur.), The Handbook of Intellectual Disability and Clinical Psychology Practice (str. 3-49). London, Združeno kraljestvo: Routledge.

Carr, A. in O‘Reilly, G. (2007b). Lifespan development and the family cycle. V A. Carr, G. O'Reilly, P. N. Walsh in J. McEvoy (ur.), The Handbook of Intellectual Disability and Clinical Psychology Practice (str. 50-91). London, Združeno kraljestvo: Routledge.

Carr, J. (1988). Six weeks to twenty-one years old: A longitudinal study of children with Down's syndrome and their families. Journal of Child Psychology and Psychiatry, 29(4), 407-431.

Carr, J. (2005). Stability and change in cognitive ability over the life span: A comparison of populations with and without Down's syndrome. Journal of Intellectual Disability Research, 49(12), 915-928.

Carr, J. (2012). Six weeks to 45 years: A longitudinal study of a population with Down syndrome. Journal of Applied Research in Intellectual Disabilities, 25, 414-422.

Dykens, E. M., Hodapp, R. M., Walsh, K. in Nash, L. J. (1992). Profiles, correlates, and trajectories of intelligence in Prader-Willi syndrome. Journal of the American Academy of Child \& Adolescent Psychiatry, 31, 1125-1130.

Facon, B. (2008). A cross-sectional test of the similar trajectory hypothesis among adults with mental retardation. Research in Developmental Disabilities, 29, 29-44.

Fisher, M. in Zeaman, D. (1970). Growth and decline of retardate intelligence. International Review of Research in Mental Retardation, 4, 151-189.

Goodman, J. F. in Cameron, J. (1978). The meaning of IQ constancy in young retarded children. The Journal of Genetic Psychology, 132, 109-119.

Hall, S. S., Burns, D. D. in Lightbody, A. A. (2008). Longitudinal changes in intellectual development in children with fragile X syndrome. Journal of Abnormal Child Psychology, 36, 927-939.

Hodapp, R. M., Burack, J. A. in Zigler, E. (1998). Developmental approaches to mental retardation: A short introduction. V J. A. Burack, R. M. Hodapp in E. Zigler (ur.), Handbook of mental retardation and development (str. 3-19). Cambridge, Združeno kraljestvo: Cambridge University Press. 
Kaufman, A. S., Reynolds, C. R. in McLean, J. E. (1989). Age and WAIS-R intelligence in national sample of adults in the 20-74 year age range: A cross-sectional analysis with educational level controlled. Intelligence, 13(3), 235-253.

Keogh, B. K., Bernheimer, L. P. in Guthrie, D. (1997). Stability and change over time in cognitive level of children with delays. American Journal on Mental Retardation, 101(4), $365-373$.

Kodrič, J. (2010). Psihološko ocenjevanje otrok z motnjo v duševnem razvoju [Psychological assessment of children with intellectual disability]. V B. D. Jurišić in A. Šelih (ur.), 3. posvet na temo Usmerjanje otrok z Downovim sindromom in drugih otrok z motnjo $v$ duševnem razvoju [3rd meeting concerning educational councelling for children with Down Syndrome and other children with intellectual disability] (str. 7-20). Ljubljana, Slovenija: Sožitje, Sekcija za Downov sindrom.

Kovačič, D. (2016). Psihologija oseb s telesno in povezano duševno zmanjšano zmožnostjo [Psychology of persons with physical and related mental disability]. Ljubljana, Slovenija: Univerzitetni rehabilitacijski inštitut - Soča.

Kumar, I., Singh, A. R. in Akhtar, S. (2009). Social development of children with mental retardation. Industrial Psychiatry Journal, 18(1), 56-59.

Lifshith, H., Weiss, I., Tzuriel, D. in Tzemach, M. (2010). New model of mapping difficulties in solving analogical problems among adolescents and adults with intellectual disability. Research in Developmental Disabilities, 32, 326-344.

Lifshitz-Vahav, H. (2014). Adults with intellectual disability are accessible to change beyond the limitation of age from vision to empirical findings. Transylvanian Journal of Psychology, 153-175.

Loveland, K. A. in Tunali-Kotolski, B. (1998). Development of adaptive behavior in persons with mental retardation. V J. A. Burack, R. M. Hodapp in E. Zigler (ur.), Handbook of mental retardation and development (str. 521-562). Cambridge, Združeno kraljestvo: Cambridge University Press.

Moravec Berger, D. (ur.) (2005). Mednarodna klasifikacija bolezni in sorodnih zdravstvenih problemov za statistične namene: MKB-10: Deseta revizija [International statistical classification of diseases and related health problems: ICD-10: 10th revision]. Ljubljana, Slovenija: Inštitut za varovanje zdravja Republike Slovenije.

Stropnik, S. in Kodrič, J. (2012). Prilagoditvene spretnosti [Adaptive skills]. Psihološka obzorja, 21(2), 41-50.

Svetina, M. (2002). Valentine test inteligentnosti za otroke: Vprašanja prenove [Valentine test of intelligence for children: Revision concerns]. Psihološka obzorja, 11(3), $7-22$.

Toličič, I. (1962). Inteligentnosti testi za otroke [Tests of intelligence for children]. Ljubljana: Psihološki inštitut Filozofske fakultete.
Udwin, O. in Kuczynski, A. (2007). Behavioural phenotypes in genetic syndromes associated with intellectual disability. V A. Carr, G. O‘Reilly, P. N. Walsh in J. McEvoy (ur.), The Handbook of Intellectual Disability and Clinical Psychology Practice (str. 488-528). London, Združeno kraljestvo: Routledge.

Valentine, C. W. (1953). Intelligence Tests for Children. London: Methuen.

Vig, S. in Jedrysek, E. (1995). Adaptive behavior of young urban children with developmental disabilities. Mental Retardation, 33(2), 90-98.

Zakon o usmerjanju otrok s posebnimi potrebami /ZUOPP-1/ (2011). Uradni list RS, št. 58 (22. 7. 2011). Pridobljeno s strani https://www.uradni-list.si/glasilo-uradni-list-rs/ vsebina? urlid $=201158 \&$ stevilka $=2714$ 